\title{
The Metabolism of cis- and trans-Decalin
}

\author{
By T. H. ELLIOTT, J. S. ROBERTSON AND R. T. WILLIAMS \\ School of Pharmacy, University of Singapore, Singapore, and \\ Department of Biochemistry, St Mary's Hospital Medical School, London, W. 2
}

(Received 3 January 1966)

\begin{abstract}
1. The metabolism of cis- and trans-decalin in the rabbit has been investigated. 2. Both hydrocarbons were oxidized to racemic secondary alcohols and excreted as ether glucuronides in amounts equal to about $60 \%$ of the dose administered. The principal glucuronides were isolated as triacetyl methyl esters and as sodium salts. 3. cis-Decalin gave rise mainly to $( \pm)$-cis-cis-2-decalol, together with a little cis-trans-2-decalol, and trans-decalin mainly to $( \pm$ )-trans-cis-2-decalol and a small amount of trans-trans-2-decalol. 4. These results suggest that biological oxidation of the decalins does not occur via a free-radical mechanism. An attempt is made to explain why racemic alcohols are obtained, rather than the more typical optically active products of enzymic reaction, and a mechanism is proposed. It is suggested that enzymes similar to steroid hydroxylases are involved.
\end{abstract}

Both cis- and trans-decalin (decahydronaphthalene) are important commercial solvents. A mixture of both isomers is technically obtained from naphthalene or tetralin by catalytic hydrogenation (Kilheffer, 1925), and as such is used as a thinner and solvent in the paint and varnish industries. It is also a good solvent for oils, fats, waxes, latex and resins such as dammar and mastic, and so finds application in the preparation of shoe creams and floor waxes and as a constituent of cleaning fluids and lubricating oils.

In general, decalin is regarded as being a nontoxic industrial solvent. However, Cardani (1942) carried out chronic toxicity studies in rabbits, and reported that $1.8 \mathrm{mg}$./l. by inhalation caused death in 8-23 days, preceded by clonic convulsions. The liver was damaged and the kidneys showed necrosis. In the human, Cardani (1942) found intense pruritus and vesicular eczema in a patient who had had prolonged contact with the liquid; kidney involvement was suggested by the presence of albumin and leucocytes in the urine.

An investigation into the metabolism of decalin (mixed decalin isomers) in dogs was carried out by Bernhard (1939). After oral administration, he isolated an unidentified decahydronaphthol from the urine, equivalent to $37.7 \%$ of the hydrocarbon given, and he stated that there was very little glucuronide formed. This finding contrasts with the results reported in the present paper. After oral administration of cis- or trans-decalin to rabbits, approx. $60 \%$ of the hydrocarbons was excreted in the urine as glucuronides. The aglycones were found to be mixtures of two racemic 2-decalols in each case.

To explain these findings it has been assumed that an enzyme hydroxylates asymmetrically each of the effectively enantiomeric forms of the apparently symmetrical molecules of which these hydrocarbons are composed, thus producing equal amounts of a (+)-2-decalol and a (-)-2-decalol. Since only the 2-position seems to be attacked in vivo, there are grounds for assuming that oxidation does not take place by a free-radical mechanism.

\section{MATERIALS}

All melting points are uncorrected.

cis-Decalin was prepared by low-pressure hydrogenation of tetralin in acetic acid, at room temperature, in the presence of Adams catalyst. After removal of catalyst, extraction, drying and removal of solvent, the liquid remaining was fractionally distilled; that fraction boiling at $192^{\circ}$ was collected, $n_{\mathrm{D}}^{23} 1 \cdot 4783$. Hückel (1925) gives b.p. $193^{\circ}, n_{\mathrm{D}}^{20} 1 \cdot 4811$. The infrared spectrum was that of cis-decalin, with distinctive absorption bands at 878, 1010 and $1170 \mathrm{~cm} .-1$, and no absorption at $927 \mathrm{~cm} .-1$ (indicating absence of the trans isomer; Seidman, 1951).

trans-Decalin was prepared from the cis isomer above by equilibrating with anhydrous $\mathrm{AlCl}_{3}$ for $48 \mathrm{hr}$. (Zelinsky \& Torowa-Polak, 1932). Removal of catalyst followed by fractional distillation of the reaction product yielded pure trans-decalin, b.p. $185^{\circ}, n_{\mathrm{D}}^{25} 1 \cdot 4683$. Hückel (1925) gives $n_{\mathrm{D}}^{24}$ 1.4696. The infrared spectrum showed characteristio absorption bands at 1140, 1058, 1029, 973, 927, 841 and $828 \mathrm{~cm} .^{-1}$, and no absorption at 1170,1010 and $878 \mathrm{~cm} .^{-1}$, indicating absence of the cis isomer (Seidman, 1951).

Reference compounds, namely the triacetyl methyl 
esters and sodium salts of $( \pm)$-cis-cis-2- and ( \pm )-transcis-2-decalyl glucuronic acid, and the corresponding aglycones, together with $( \pm)$-cis-trans-2- and ( \pm )-transtrans-2-decalol, are described in the preceding paper (Elliott, Robertson \& Williams, 1966).

\section{METHODS AND RESULTS}

Animals and diet. Adult doe albino rabbits weighing 1-2kg. were used. They were kept on a constant diet consisting of $4 \mathrm{oz}$. of sweet potatoes (Ipomoea batatas) and $4 \mathrm{oz}$. of kangkong (Ipomoea reptans) daily. No additional water was given.

Administration of dose. The compounds were administered by stomach tube, followed by about $20 \mathrm{ml}$. of water.

Analytical methods. Glucuronic acid was determined by the method of Hanson, Mills \& Williams (1944) as modified by Paul (1951); the results are given in Table 1. Ethereal sulphate was determined by the turbidimetric method of Sperber (1948), and mercapturic acid by the iodinetitration method of Stekol (1936); practically no increase in ethereal sulphate and no increase in mercapturic acid were detected.

Differential infrared spectroscopy. When equal concentrations of the same compound in matched cells are placed in the reference and sample beams of a spectrophotometer, a straight-line spectrum is obtained. If a second substance is now added to one cell, the resulting spectrum is that of the added component. Conversely, where there is a mixture of a known and an unknown component in the reference cell, the spectrum of the unknown component may be obtained by having present in the detecting cell an equal concentration of the known component. This technique has proved very useful when the second component is a

Table 1. Glucuronic acid excretion of the isomeric decalins

Experimental details are given in the text. Three animals were used for each determination.

$\begin{array}{cccc}\begin{array}{c}\text { Compound } \\ \text { administered }\end{array} & \begin{array}{c}\text { Dose (m- } \\ \text { moles/kg. } \\ \text { body wt.) }\end{array} & \text { Average } & \begin{array}{c}\text { Percentage of dose } \\ \text { excreted as glucuronide }\end{array} \\ \text { cis-Decalin } & 3.53 & 67 & 64-69.5 \\ \text { trans-Decalin } & 3.9 & 63 & 39-62.9\end{array}$

minor one, which is difficult to isolate owing to volatility, very low concentration or isomerism with the major component.

Chromatography. Analytical thin-layer chromatography, with plates or slides coated with a $0.25 \mathrm{~mm}$. layer of silica gel H (E. Merck A.-G., Darmstadt, Germany) or radial preparative thin-layer chromatography, as described by Elliott et al. (1966), was used. Solvent system 1 consisted of butan-1-ol-aq. $\mathrm{NH}_{3}$ (sp.gr. $\left.0 \cdot 88\right)(4: 1, \nabla / v)$ and system 2 was hexane-ethyl acetate $(9: 1, \quad \nabla / v)$. Ion-exchange chromatography as described by Elliott et al. (1966) was used for the isolation of glucuronides.

cis-Decalin. This hydrocarbon $(2 \mathrm{ml}$. or $1.79 \mathrm{~g}$.) was administered to each of three rabbits. Chromatography of the urine showed the presence of two spots giving a naphtharesorcinol reaction (see Elliott, Tao \& Williams, 1965), with $R_{F}$ values 0.14 (major) and 0.10 (minor) in system 1 . Isolation of the glucuronide from the dried urine by ionexchange chromatography yielded $4 \cdot 7 \mathrm{~g}$. of gum that could not be crystallized. Half of the gum was converted into the sodium salt (Elliott et al. 1966) and the remainder into the triacetyl methyl ester by first methylating with diazomethane in ether and then acetylating with acetic anhydride and pyridine. Recrystallization of the crude ester from methanol yielded $190 \mathrm{mg}$. of pure ester, m.p. 162-163.5 $5^{\circ}$ not depressed when mixed with pure methyl $[( \pm)$-cis-cis-2decalyl tri- $O$-acetyl- $\beta$-D-glucosid]uronate (Elliott et al. 1966), $[\alpha]_{\mathrm{D}}^{24}-38 \pm 2^{\circ}$ (c 1 in chloroform) (Found: C, 58.9; $\mathrm{H}, 7 \cdot 2$. $\mathrm{C}_{23} \mathrm{H}_{34} \mathrm{O}_{10}$ requires $\mathrm{C}, 58 \cdot 8 ; \mathrm{H}, 7 \cdot 3 \%$ ). Hydrolysis of the ester with $\mathrm{N}-\mathrm{HCl}$ for $3 \mathrm{hr}$. gave $( \pm)$-cis-cis-2-decalol, m.p. $105^{\circ},[\alpha]_{\mathrm{D}}^{24} 0^{\circ}$ (c 1 in chloroform), $R_{F} 0 \cdot 19$ (system 2). The infrared spectrum was identical with that of cis-cis-2-decalol.

The sodium salt, after purification by radial preparative thin-layer chromatography, had $R_{F} 0 \cdot 14$ (system 1) and $[\alpha]_{\mathrm{D}}^{24}-41 \cdot 7 \pm 2^{\circ}$ (c 1 in methanol). Hydrolysis with snailcrop juice containing $\beta$-glucuronidase (Elliott et al. 1966) yielded an oil that, when chromatographed, revealed two spots giving a phosphomolybdic acid reaction (Elliott et al. 1966) of $R_{F}$ values 0.19 (major) and 0.34 (minor) in system 2. The oil slowly deposited crystals of $( \pm)$-cis-cis-2-decalol, m.p. $105^{\circ}, R_{F} 0 \cdot 19$ (system 2). To determine the nature of the second component the uncrystallizable portion of the oil was examined by differential infrared spectroscopy; the differential spectrum was that of cis-trans-2-decalol.

trans-Decalin. This decalin ( $2 \mathrm{ml}$. or $1.74 \mathrm{~g}$.) was administered to each of three albino rabbits. Chromatography of the $24 \mathrm{hr}$. urine revealed the presence of two glucuronides of $R_{F}$ values 0.132 (major) and 0.09 (minor) in system 1 .

Table 2. Properties of glucuronides and aglycones of cis-and trans-decalin

\begin{tabular}{|c|c|c|c|c|c|c|c|c|c|}
\hline \multirow[b]{2}{*}{$\begin{array}{l}\text { Compound } \\
\text { adminis- } \\
\text { istered }\end{array}$} & \multirow[b]{2}{*}{$\begin{array}{c}\text { Glucuronide } \\
R_{F} \text { in } \\
\text { system } 1\end{array}$} & \multicolumn{2}{|c|}{$\begin{array}{c}\text { Triacetyl methyl } \\
\text { ester }\end{array}$} & \multicolumn{3}{|c|}{ Sodium salt } & \multicolumn{3}{|c|}{ Aglycone } \\
\hline & & m.p. & $\begin{array}{c}{[\alpha]_{\mathrm{D}}^{24}} \\
(\mathrm{c} 1 \mathrm{in} \\
\left.\mathrm{CHCl}_{3}\right)\end{array}$ & $\begin{array}{c}R_{F} \text { in } \\
\text { system } 1\end{array}$ & $\begin{array}{c}R_{F} \text { in } \\
\text { system } 2\end{array}$ & $\begin{array}{c}{[\alpha]_{D}^{24}} \\
(c 1 \text { in } \\
\text { methanol })\end{array}$ & $\begin{array}{c}R_{F} \text { in } \\
\text { system } 2\end{array}$ & m.p. & $\begin{array}{c}{[\alpha]_{\mathrm{D}}^{24}} \\
(c 1 \text { in } \\
\left.\mathrm{CHCl})_{3}\right)\end{array}$ \\
\hline cis-Decalin & $\begin{array}{l}0.14 \text { (major) } \\
0.10 \text { (minor) }\end{array}$ & $162-163 \cdot 5^{\circ}$ & $-\mathbf{3 8}^{\circ}$ & 0.67 & $0 \cdot 14$ & $-41 \cdot 7^{\circ}$ & $\begin{array}{l}0.19 \text { (major) } \\
0.34 \text { (minor) }\end{array}$ & $\begin{array}{c}105^{\circ} \\
-\end{array}$ & $0^{\circ}$ \\
\hline trans-Decalin & $\begin{array}{l}0.13 \text { (major) } \\
0.09 \text { (minor) }\end{array}$ & $156-158$ & -23 & 0.66 & $0 \cdot 13$ & $-41 \cdot 8$ & $\begin{array}{l}0.26 \text { (major) } \\
0.19 \text { (minor) }\end{array}$ & $\begin{array}{c}73-74 \\
-\end{array}$ & $\begin{array}{l}0 \\
-\end{array}$ \\
\hline
\end{tabular}


Isolation of the glucuronide fraction by ion-exchange chromatography yielded $4 \mathrm{~g}$. of gum that could not be crystallized. The gum ( $2 \mathrm{~g}$.) was converted into the sodium salt and the remainder into the triacetyl methyl ester. Repeated recrystallization yielded $130 \mathrm{mg}$. of pure ester, m.p. $156-158^{\circ}$ not depressed when mixed with pure methyl $[( \pm)$-trans-cis-2-decalyl tri- $O$-acetyl- $\beta$-D-glucosid]uronate, $[\alpha]_{\mathrm{D}}^{24}-23 \pm 2^{\circ}$ (c 1 in chloroform). Acid hydrolysis of $100 \mathrm{mg}$. of this ester with $\mathrm{N}-\mathrm{HCl}$ yielded $20 \mathrm{mg}$. of $( \pm)-$ trans-cis-2-decalol, m.p. 73-74', whose infrared spectrum was that of pure trans-cis-2-decalol. Enzyme hydrolysis, as described above, of the sodium salt that had been purified by preparative chromatography and had $[\alpha]_{\mathrm{D}}^{24}$ $-41 \cdot 8 \pm 2^{\circ}$ (c 1 in methanol) yielded an oil which on chromatography was found to consist of two alcohols of $R_{F}$ values 0.255 (major) and 0.185 (minor) in system 2. The oil slowly deposited crystals of $( \pm)$-trans-cis-2-decalol, m.p. 74-75,$[\alpha]_{D}^{24} 0^{\circ}$ (c 1 in chloroform). The infrared spectrum matched that of pure trans-cis-2-decalol. The oil remaining was examined by differential infrared spectroscopy; the differential spectrum obtained resembled that of trans-trans-2-decalol.

\section{DISCUSSION}

After administration of both cis- and transdecalin to rabbits, about $60 \%$ of the dose given was excreted as ether-linked glucuronides. The aglycones isolated after feeding with cis-decalin were ( \pm )-cis-cis-2-decalol (mainly) and ( \pm )?-cis-trans2-decalol, whereas a trans-decalin feed yielded

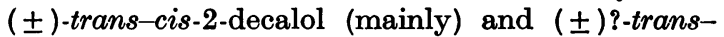
trans-2-decalol. Elliott, Parke \& Williams (1959) found that the major oxidation product of $\left[{ }^{14} \mathrm{C}\right]$ cyclohexane in the rabbit was cyclohexanol. The trans-1,2-diol was also formed and by isotope dilution it was estimated to be present in the mono-ol/diol ratio $13: 1$, although the ratio tended to fall a little as the experiment was prolonged.

No diol was detected during the metabolism in the rabbit of $\left[{ }^{14} \mathrm{C}_{7}\right]$ methylcyclohexane (Elliott et al. 1965). Only secondary alcohols were isolated or detected, which is consistent with the findings of the present investigation. It was also found that $\left[{ }^{14} \mathrm{C}_{7}\right]$ methylcyclohexane was oxidized at positions 2,3 or 4 , though mainly in positions 3 or 4 .

Free-radical attack is one possible mode of oxidation (Smith, 1950). However, if this were the biological oxidizing mechanism for the decalins, a mixture of alcohols should result. Indeed, peroxidation of the decalins has been shown to proceed at all positions, though mainly at positions 9 and 10 , with subsequent formation of all possible secondary and tertiary alcohols (Jaffe, Steadman \& McKinney, 1963). This contrasts strongly with the biological oxidation products of the decalins, which result from attack at one point only in the molecule. This would seem to indicate that biological oxidation of the decalins takes place by a mechanism other than typical free-radical attack.
Reference to the hydroxylating enzymes listed by Hayaishi (1962) indicates that, on the basis of substrate attacked, hydroxylases requiring steroids as substrates are likely to be significant in the present investigation. These steroid oxygenases all appear to be mixed-function oxidases (Mason, 1957) that transfer one atom of a molecule of atmospheric oxygen to the substrate and reduce the remaining atom of oxygen, NADPH being the specific reducing agent (Usui \& Yamasaki, 1960; Halkerston, Eichhorn \& Hechter, 1961). Most of these oxygenases effect introduction of the hydroxyl group into specific sites in steroids, e.g. $7 \alpha$-hydroxylases introduce a hydroxyl group into the $7 \alpha$ position and $11 \beta$-hydroxylases do likewise at the $11 \beta$-position. Of these enzymes, $11 \beta$-hydroxylase is the most widely investigated. $11 \alpha$-Hydroxylase activity has been demonstrated in cultures of Rhizopus nigricans (Hayano, Gut, Dorfman, Sebek \& Peterson, 1958). It is proposed that these steroid hydroxylases or closely allied enzymes are concerned in the introduction of hydroxyl groups into both cis- and trans-decalin.

It must be noted that there are differences between these two substrates. The steroids are oxygenated at position 3, and, moreover, are optically active, as are the subsequent hydroxylated products. On the other hand, the decalins are saturated hydrocarbons, optically inactive, as are the products of biological hydroxylation. In order that a racemic decalol be obtained, (+)- and (-)alcohols must have been produced in equal amounts. This must mean that, although trans-decalin, for example, is a symmetrical molecule (Fig. 1), when it becomes attached to the hydroxylating enzyme surface the spatial requirements of this attachment are such that it has to be considered as being composed of two enantiomers (Fig. 2). It is assumed that the orientation of the substrate is such as to expose a $\beta$-carbon atom to hydroxylation while protecting an $\alpha$-carbon atom. The same arguments apply to the hydroxylation of cis-decalin (Fig. 1), when racemic cis-cis-2-decalol is formed.

An enzyme similar to $11 \alpha$-hydroxylase is presumed to effect the hydroxylation of the decalins to form the small amounts of cis-trans-2- and transtrans-2-decalol found in the urine.

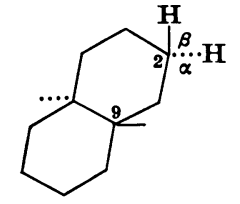

(a)

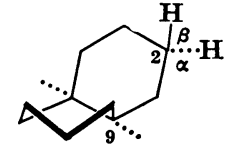

(b)
Fig. 1. trans-Decalin (a) and cis-decalin (b). 

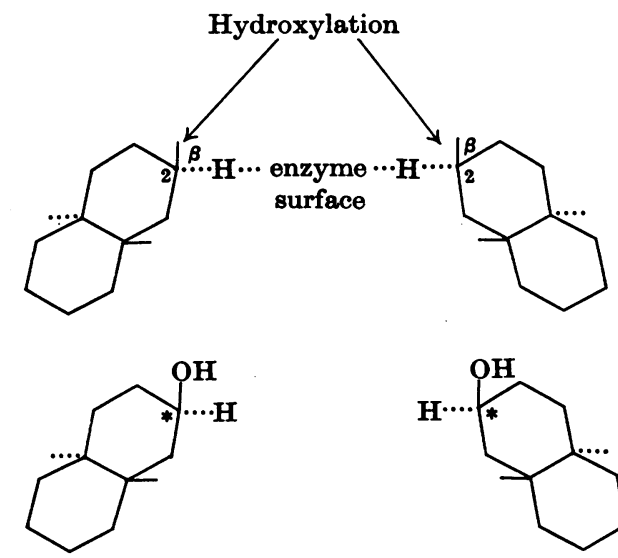

$(+)$ - or (-)-trans-cis 2-Decalol

Fig. 2. $\beta$-Hydroxylation of trans-decalin; * denotes a new asymmetric carbon atom.

\section{REFERENCES}

Bernhard, K. (1939). Hoppe-Seyl. Z. 257, 49. Cardani, A. (1942). Med. d. Lavoro, p. 33.
Elliott, T. H., Parke, D. V. \& Williams, R. T. (1959). Biochem. J. 72, 193.

Elliott, T. H., Robertson, J. S. \& Williams, R. T. (1966). Biochem. J. 100, 393.

Elliott, T. H., Tao, R. C. C. \& Williams, R. T. (1965). Biochem. J. 85, 70.

Halkerston, I. D. K., Eichhorn, J. \& Hechter, O. (1961). J. biol. Chem. 236, 374.

Hanson, S. W. F., Mills, G. T. \& Williams, R. T. (1944). Biochem. J. 38, 274.

Hayaishi, O. (1962). In Oxygenases, p. 13. Ed. by Hayaishi, O. New York and London: Academic Press Inc.

Hayano, M., Gut, M., Dorfman, R. I., Sebek, O. K. \& Peterson, D. H. (1958). J. Amer. chem. Soc. 80, 2336.

Hückel, W. (1925). Liebigs Ann. 441, 1.

Jaffe, F., Steadman, T. R. \& McKinney, R. W. (1963). J. Amer. chem. Soc. 85, 351.

Kilheffer, E. H. (1925). Chem. Zbl. 11, 827.

Mason, H. S. (1957). Advanc. Enzymol. 19, 79.

Paul, J. (1951). Ph.D. Thesis: University of Glasgow.

Seidman, J. (1951). Analyt. Chem. 23, 559.

Smith, J. N. (1950). Symp. biochem. Soc. 5, 15.

Sperber, I. (1948). J. biol. Chem. 172, 441.

Stekol, J. A. (1936). J. biol. Chem. 113, 279.

Usui, T. \& Yamasaki, K. (1960). J. Biochem., Tokyo, 48, 226.

Zelinsky, N. \& Torowa-Polak, M. (1932). Ber. dtsch. chem. Ges. 65, 1299. 